\title{
Cycling of biologically available nitrogen in riverine humic substances between marine bacteria, a heterotrophic nanoflagellate and a photosynthetic dinoflagellate
}

\author{
P. Carlsson ${ }^{1, *}$, E. Granéli ${ }^{1}$, A. Z. Segatto ${ }^{2}$ \\ ${ }^{1}$ University of Kalmar, Department of Marine Sciences, PO Box 905, S-391 29 Kalmar, Sweden \\ ${ }^{2}$ University of Lund, Department of Marine Ecology, Ecology Building, S-223 62 Lund, Sweden
}

\begin{abstract}
The effects of freshwater dissolved organic matter (DOM) on the growth of a community of coastal marine bacteria, a heterotrophic flagellate (Cafeteria roenbergensis) and an autotrophic dinoflagellate (Prorocentrum minimum) were studied in an experimental system incubated under laboratory conditions. The DOM used was in the form of riverine-isolated humic substances (HS). The addition of HS increased bacterial growth, which in turn increased growth of C. roenbergensis. P. minimum attained higher abundance, higher chlorophyll a content per cell and a higher cellular nitrogen (N) content when grown with HS addition. In the treatment with $P$. minimum and bacteria approximately $35 \%$ of the humic-associated $\mathrm{N}$ was utilized by the organisms, as indicated by the increase of particulate $\mathrm{N}$ in $P$. minimum and bacteria cells. There was no net accumulation of inorganic $\mathrm{N}$ in any treatment, indicating that bacteria acted as a sink for $\mathrm{N}$ when utilizing the HS as substrate. Moreover, grazing activity by $C$. roenbergensis did not cause any significant accumulation of inorganic $\mathrm{N}$ in treatments with $C$. roenbergensis and bacteria, suggesting that bacteria used the inorganic $N$ released by the grazers. Thus, the increased growth of $P$. minimum with HS present was probably not caused by bacterial mineralization of inorganic nitrogen, but could have been caused by the algae using dissolved organic nitrogen compounds.
\end{abstract}

KEY WORDS: Humic substances · Organic nitrogen · Microbial loop

\section{INTRODUCTION}

Inputs of riverine dissolved organic matter (DOM) represent a significant source of carbon (C), nitrogen $(\mathrm{N})$ and phosphorus $(\mathrm{P})$ to coastal ecosystems (Albright 1983, Rydberg et al. 1990, Chin-Leo \& Benner 1992). This riverine DOM can increase bacterial production in coastal waters (Albright 1983, Kirchman et al. 1989, Chin-Leo \& Benner 1992, Carlsson et al. 1995), and it has recently been shown that high-molecular-weight $(\mathrm{HMW})(>1 \mathrm{kDa}$ ) DOM, the dominant fraction, in river water is more available for bacterial utilization than the low-molecular-weight (LMW) $\quad(<1 \quad \mathrm{kDa})$ DOM (Amon \& Benner 1996). Increased bacterial production

\footnotetext{
•E-mail: per.carlsson@ng.hik.se
}

due to utilization of allochthonous DOM will to some extent be available to higher trophic levels in coastal waters by the 'microbial loop' (Azam et al. 1983). Thus, the ability of a coastal marine pelagic system to process the input of riverine DOM is important for the production and perhaps also the structure of coastal pelagic ecosystems in areas receiving large riverine inputs of DOM.

A large proportion of the riverine DOM is composed of what is known as humic substances (HS), i.e. macromolecular organic compounds with complicated structure (Thurman 1985). The amount of HS entering coastal waters is especially large in areas where the drainage area is dominated by forests (e.g. Andersson et al. 1991). Humic substances have usually been considered as refractory compounds, not available for bio- 
logical utilization (Fenchel \& Blackburn 1979, Geller 1983). However, bacteria have been shown to use HS as substrate (e.g. Tranvik 1988, Moran \& Hodson 1990) and phytoplankton growth can also increase when HS are added to algal cultures (Granéli \& Moreira 1990) or to natural plankton communities (Carlsson et al. 1993, 1995).

Phytoplankton production in many coastal areas is limited by the availability of $\mathrm{N}$ (e.g. Ryther \& Dunstan 1971. Howarth 1988, Granéli et al. 1990, Paerl 1993). The supply of riverine DOM to coastal waters also supplies a pool of dissolved organic $N$ (DON) that is a potential $\mathrm{N}$ source for phytoplankton. Very little is still known about the direct utilization of different components of the DON by phytoplankton in natural systems. Price et al. (1985) found a significantly higher increase in phytoplankton particulate $\mathrm{N}$ than the utilization of inorganic $N$ and urea together could account for. This was perhaps due to the utilization of different DON compounds by the phytoplankton community in the stratified water mass they investigated. Several phytoplankton species are able to use $\mathrm{N}$ bound in different LMW organic compounds such as urea and free and combined dissolved amino acids (see reviews by Flynn \& Butler 1986, Antia et al. 1991), and some phytoplankton species have cell-surface amino acid oxidases which oxidize amino acids and primary amines to ammonium for cellular uptake (Palenik \& Morel 1990). HMW polymeric compounds such as HS are too large to pass the cytoplasmic membrane (Payne 1980) and must be degraded enzymatically before uptake (Raven 1980), or taken up actively via pinocytosis, a mechanism in which the plasma membrane extends and forms a vesicle enclosing liquid containing the HMW compounds (Klut et al. 1987); this mechanism has so far been very little studied and the importance of it for phytoplankton nutrition is virtually unknown. However, Legrand \& Carlsson (1998) recently showed that the dinoflagellate Alexandrium catenella could take up large $(2000 \mathrm{kDa})$ fluorescein isothiocyanate (FITC)-labeled dextrans, presumably by pinocytosis.

$N$ in the HS can also be made available for phytoplankton in inorganic form either by bacterial mineralization (e.g. Cotner \& Gardner 1993, Gardner et al. 1994), depending on the relative $C$ and $N$ availability of the substrate (Goldman et al. 1987), or by excretion from grazers such as heterotrophic flagellates and ciliates grazing on bacteria (Caron \& Goldman 1990) that have assimilated the humic-associated N. Photochemical release of ammonium from HS was also recently described by Bushaw et al. (1996), which presents another mechanism by which inorganic $\mathrm{N}$ can become available for bacterial and phytoplankton uptake.

The aim of this experiment was to investigate the effects of addition of riverine HS on growth, utilization of humic-bound $\mathrm{N}$, and interactions between organisms in an artificially constructed, $\mathrm{N}$-limited plankton system, consisting of a coastal marine bacterial community, a heterotrophic bacterial grazer (Cafeteria roenbergensis) and a photosynthetic dinoflagellate (Prorocentrum minimum).

\section{MATERIALS AND METHODS}

Cultures of Prorocentrum minimum and Cafeteria roenbergensis. The dinoflagellate Prorocentrum minimum (non-axenic strain LAC 6 from the culture collection of Department of Marine Ecology, University of Lund) was grown in seawater (26\% salinity) $\mathrm{f} / 2$ medium (Guillard \& Ryther 1962) as $1 / 20$ of the original description with nitrate modified in order to give an $N: P$ ratio of 16 in the medium. Thus, the initial nitrate and phosphate concentrations in the media were $58 \mu \mathrm{M}$ and $3.6 \mu \mathrm{M}$, respectively. The culture was kept at the same conditions as the experimental bottles (see 'Water sampling and experimental setup'). The culture was used as an inoculum when it had reached a density of more than 50000 cells $\mathrm{ml}^{-1}$, with presumably low concentrations of nitrate and phosphate.

The heterotrophic flagellate Cafeteria roenbergensis was obtained from the Department of Botany, University of Copenhagen, Denmark, and grown in seawater (26\% salinity), with a Pseudomonas sp. bacterium as a food source, without any inorganic nutrient additions, at the same temperature and light conditions as the culture of Prorocentrum minimum. The C. roenbergensis culture that was used as inoculum was grown until the density of cells was more than 400000 cells $\mathrm{ml}^{-1}$. Since the inoculum of both $P$. minimum and $C$. roenbergensis constituted only 1 to $3 \%$ of the water volume in the 5 I experimental bottles, only small amounts of inorganic nutrients were introduced together with the inoculum, with no detectable increase in ammonium, nitrate or phosphate concentrations after inoculation.

Isolation of humic substances (HS). HS were isolated from river Fylleån water, county of Halland, Sweden. This river has a drainage area dominated by forests and has a medium concentration of HS the

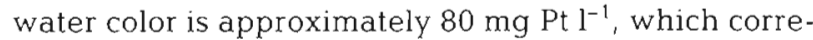
sponds to a dissolved organic carbon (DOC) concentration of 10 to $14 \mathrm{mg} \mathrm{C} \mathrm{l}^{-1}$, Kullberg \& Petersen 1987]. The separation and concentration of HS were done using the methods described by Thurman \& Malcolm (1981) and Petersen et al. (1987). The water was acidified to $\mathrm{pH} 1.8$ with sulphuric acid and filtered through 50 and $1 \mu \mathrm{m}$ cartridge filters (Brunswick Technetics Filterite). The filtered water was then passed through $1000 \mathrm{ml}$ of XAD-8 resin (Amberlite) in a glass column 
at a rate of $100 \mathrm{ml} \mathrm{min}{ }^{-1}$. By the commonly used operational definition, aquatic humus is the organic material which adheres to a macroporous resin (such as XAD-8) at pH 2 (Thurman 1985). The humic material was then desorbed by back-flushing the column with 2.5 bed volumes of $0.1 \mathrm{M} \mathrm{NaOH}$ followed by immediate acidification to $\mathrm{pH} 2.5$. The $\mathrm{pH}$ was then adjusted to 7.0 with $\mathrm{NaOH}$, and the HS were frozen until use. Some of the concentrated HS was freeze-dried and stored in glass scintillation vials for later analyses of total $\mathrm{C}, \mathrm{N}$ and P. Measurements of total $\mathrm{C}$ and $\mathrm{N}$ in the HS, using a Fisons NA $1500 \mathrm{CN}$-analyzer, showed that they contained $12 \% \mathrm{C}$ and $0.3 \% \mathrm{~N}$ (by weight). Thus, the HS had a C:N ratio of 40 . Analyses of the total $\mathrm{P}$ in the HS were made using the method of Solórzano \& Sharp (1980) and showed that the HS contained $0.01 \% \mathrm{P}$ (by weight). The HS we isolated had a low $C$ content compared with previous values reported in the literature (about $50 \%$ of $\mathrm{HS}$ is usually $\mathrm{C}$ according to Thurman (1985) and Hedges (1987). We therefore reanalyzed the HS for $\mathrm{C}$ and $\mathrm{N}$ content 3 times and also had a sample analyzed by a separate laboratory, with the same result. The addition of HS to the seawater increased the DOC concentration by $3.5 \mathrm{mg} \mathrm{l}^{-1}$ (measured with a Shimadzu TOC-5000 carbon analyzer, after acidification to remove inorganic $\mathrm{C}$ ). The organic $\mathrm{N}$ associated with the HS was $6.2 \mu \mathrm{M}$ of $\mathrm{N}$ (excluding the initial $\mathrm{N}$ content of the seawater).

Water sampling and experimental setup. Surface water from the southern Kattegat on the Swedish west coast was sampled on 10 October 1994 (salinity 25\%, temperature $11^{\circ} \mathrm{C}$ ) with an acid-washed polyethene bucket. The water was transported to the laboratory in polyethene $10 \mathrm{l}$ carboys kept inside insulated boxes with ice-packs. The water was filtered through a $0.2 \mu \mathrm{m}$ Sartorius cartridge filter within $4 \mathrm{~h}$ of sampling. The less than $0.2 \mu \mathrm{m}$ fraction was assumed to contain some bacteria and no heterotrophic flagellates. The small pore size of $0.2 \mu \mathrm{m}$ was used to ensure that no heterotrophic flagellates from the sample would be present in the initial water, and some bacteria were expected to pass the filter (Stockner et al. 1990). Epifluorescence microscopy of samples from the water passing the filters showed no presence of heterotrophic flagellates, but a significant number of bacteria $\left(0.3 \times 10^{6}\right.$ cells $\left.\mathrm{ml}^{-1}\right)$. To obtain treatments with heterotrophic flagellates, Cafeteria roenbergensis was added to the $0.2 \mu \mathrm{m}$ fraction to give a final concentration of 10000 cells $\mathrm{ml}^{-1}$. The bacterial concentration in this treatment became $0.6 \times 10^{6}$ cells $\mathrm{ml}^{-1}$, including the bacteria from the seawater and the bacteria included in the $C$. roenbergensis addition. Cells of the autotrophic dinoflagellate Prorocentrum minimum were added to other treatments to give a final concentration of 250 cells $\mathrm{ml}^{-1}$. Bacteria present in the original
$P$. minimum culture also increased the bacterial numbers to around $0.6 \times 10^{6}$ cells $\mathrm{ml}^{-1}$ in the treatments with $P$. minimum.

The treatments were as follows: BACT (bacteria only, $0.2 \mu \mathrm{m}$ filtered seawater), CAF (bacteria together with Cafeteria roenbergensis), PMIN (bacteria together with Prorocentrum minimum) and a CAF+PMIN treatment. To an identical set of treatments, humic substances were added (+HS). All treatments were in triplicates in 51 Pyrex glass bottles, giving a total of $8 \times 3=24$ bottles. Trace metals and vitamins according to the $\mathrm{f} / 2$ medium (Guillard \& Ryther 1962) as 1/10 of the original description were added to all treatments in order to avoid limitation of phytoplankton growth by these substances. The experimental bottles were incubated at $16^{\circ} \mathrm{C}$, light intensity (PAR) $100 \mu \mathrm{M} \mathrm{m}^{-2} \mathrm{~s}^{-1}$ (measured with QSL-100 spherical quantameter, Biospherical Instruments Inc.) and a light:dark cycle of $16: 8 \mathrm{~h}$.

Sampling and analyses of inorganic nutrients and chlorophyll a (chl a). Samples were taken daily or every second day from the experimental bottles for analyses of inorganic nutrients $\left(\mathrm{NO}_{3}{ }^{-}, \mathrm{NH}_{4}{ }^{+}, \mathrm{PO}_{4}{ }^{3-}\right)$, chl $a$, primary production, bacterial production, activity of alkaline phosphatase, and Prorocentrum minimum cell numbers. Samples for bacterial and Cafeteria roenbergensis numbers and determination of the $\mathrm{N}$ content in the $P$. minimum cells were taken initially and at the end of the experiment $(7 \mathrm{~d})$. Inorganic nutrients were analyzed using standard procedures for seawater (Valderrama 1995). Chl a was measured according to the method of Jespersen \& Christoffersen (1987). Samples $(50 \mathrm{ml}$ ) were filtered onto Whatman GF/F filters, extracted for $12 \mathrm{~h}$ in ethanol and chl a fluorescence was measured with a Turner 10 AU fluorometer, calibrated using a chl a standard solution (Sigma).

Primary production. Primary production was measured as ${ }^{14} \mathrm{C}$ uptake using the method of ErtebjergNielsen \& Bresta (1984). Two $\mu \mathrm{Ci}$ of radioactive $\mathrm{NaH}^{14} \mathrm{CO}_{3}$ (International Agency for ${ }^{14} \mathrm{C}$-determination, Copenhagen) were added to $25 \mathrm{ml}$ glass flasks and incubated for $2 \mathrm{~h}$ beside the experimental flasks. After incubation, the water was filtered through $0.45 \mu \mathrm{m}$ membrane filters (Sartorius) and filters were placed in a box with $\mathrm{HCl}$ fumes to remove remaining non-assimilated inorganic ${ }^{14} \mathrm{C}$.

Bacterial production. Bacterial production was measured as bacterial uptake of ${ }^{3} \mathrm{H}$-leucine (specific activity $150 \mathrm{Ci} \mathrm{mmol}^{-1}$, Amersham Corp.), according to Smith \& Azam (1992). The ${ }^{3} \mathrm{H}$-labeled leucine was diluted with non-radioactive L-leucine in the original vial to give a final leucine concentration of $20 \mathrm{nM}$ in a $1.7 \mathrm{ml}$ sample when $5 \mu \mathrm{l}$ of the isotope was added. Samples for bacterial production were incubated $30 \mathrm{~min}$ in the dark beside the experimental bottles. The incubation was terminated by adding TCA to the sam- 
ples (5\% final concentration) and the bacterial cells were rinsed with $5 \%$ TCA and $80 \%$ ethanol, by centrifuging $(16000 \times g, 10 \mathrm{~min})$ and aspirating the supernatant between centrifugations. Radioactivity in the samples from both primary production and bacterial production was determined with a Beckman liquid scintillation counter using Ultima Gold (Packard Inc.) scintillation cocktail. For the calculation of bacterial carbon production an intracellular isotope dilution of 2 and a carbon to protein ratio of 0.86 (weight:weight) in bacterial protein was assumed (Simon \& Azam 1989).

Cell enumeration. Samples for counts of bacteria and heterotrophic flagellates were preserved with formaldehyde (final concentration $2 \%$ ). For bacteria, $2 \mathrm{ml}$ samples were filtered on $0.2 \mu \mathrm{m}$ black polycarbonate filters (Poretics Corp.) and for heterotrophic flagellates 5 to $10 \mathrm{ml}$ were filtered on $0.8 \mu \mathrm{m}$ black polycarbonate filters (Poretics Corp.). The $0.2 \mu \mathrm{m}$ polycarbonate filter has a more accurate pore size than the $0.2 \mu \mathrm{m}$ large-volume cartridge filter (that was used to obtain the grazer-free initial water) and is generally used when bacterial cell numbers are determined by
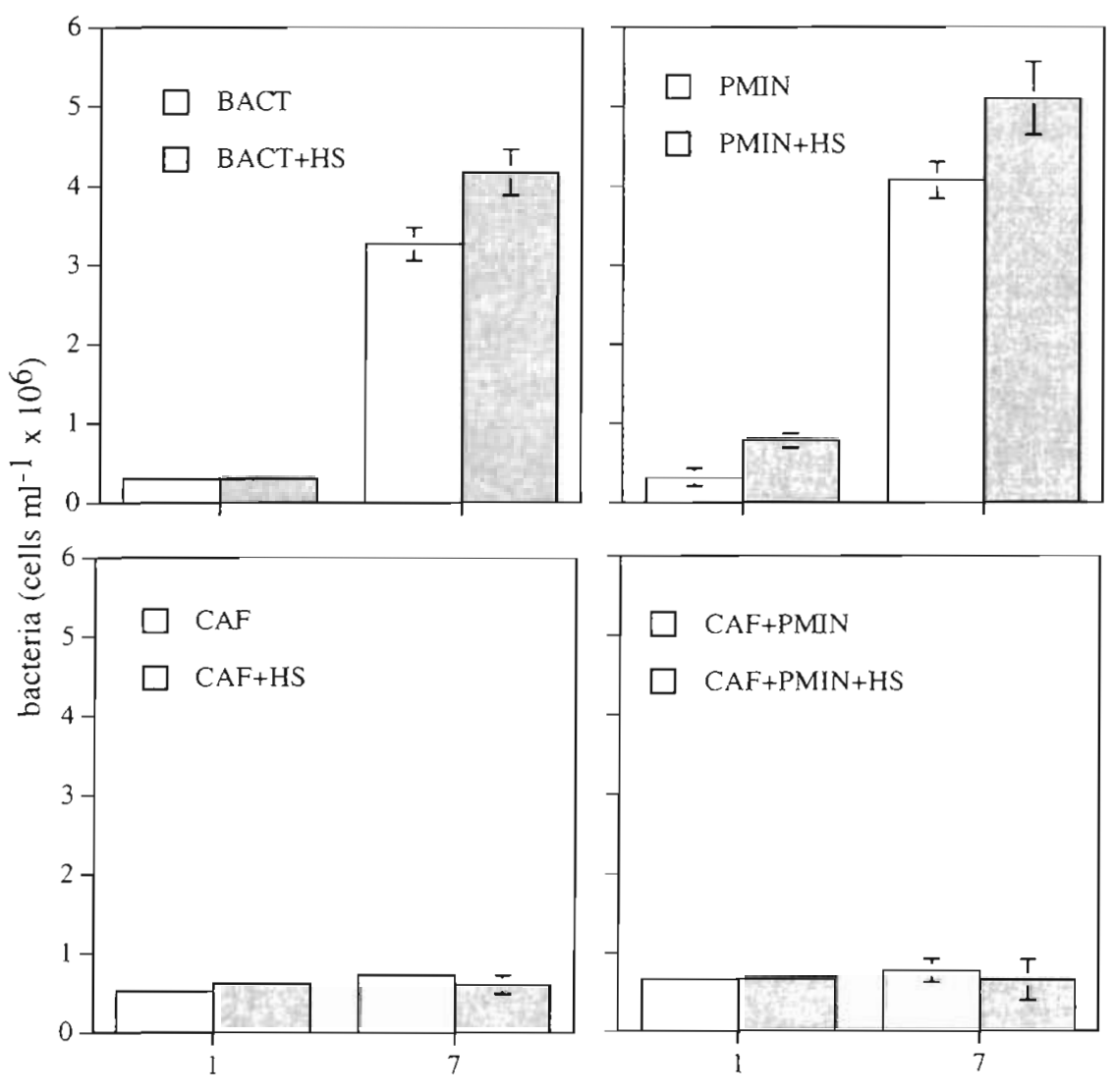

day

Fig. 1. Bacterial abundance (cells $\mathrm{ml}^{-1} \times 10^{6}$ ) on Days 1 and 7 Treatments: with bacteria only (BACT), bacteria and Prorocentrum minimum (PMIN), bacteria and Cafeteria roenbergensis (CAF) and addition of humic substances (HS) ( $\mathrm{n}=3$, mean $\pm \mathrm{SD}$ ) epifluorescence microscopy. However, we cannot rule out that some bacteria passed the $0.2 \mu \mathrm{m}$ polycarbonate filters and therefore the bacteria numbers might be slightly underestimated (Stockner et al. 1990). The bacterial counts were made according to the method described by Porter \& Feig (1980) using the fluorochrome DAPI (final concentration $20 \mu \mathrm{g} \mathrm{ml}^{-1}$ ) and an Olympus BX 50 epifluorescence microscope equipped with the following filter set: excitation 360 to $370 \mathrm{~nm}$, barrier filter $420 \mathrm{~nm}$ and dichroic mirror $400 \mathrm{~nm}$. Prorocentrum minimum samples were preserved with acidic Lugol's solution and cell counting was made using a Hiac-Royco 3000 Particle Size Analyzer calibrated with microscopical $P$. minimum cell counts using a Nikon Diaphot inverted microscope and $2.5 \mathrm{ml}$ settling chambers, according to the method described by Utermöhl (1958).

Alkaline phosphatase activity. Activity of alkaline phosphatase was determined using the substrate 4 methylumbelliferylphosphate (MUF-P) according to Petterson \& Jansson (1978). Substrate concentration was $50 \mu \mathrm{M}$ in $5 \mathrm{ml}$ samples that were incubated beside the experimental bottles for 1 to $2 \mathrm{~h}$. After the incubation, the product of substrate hydrolysis (4-methylumbelliferone [MUF]) was detected with a Turner 112 fluorometer. Calibration using 7 concentrations ranging from 5 to $150 \mathrm{nM}$ of MUF was made at every measuring occasion.

Analysis and calculation of $\mathbf{N}$ content in cells. The cellular content of $\mathrm{N}$ in Prorocentrum minimum was determined on the cells retained on precombusted $25 \mathrm{~mm}$ Whatman GF/F filters $\left(450^{\circ} \mathrm{C}, 2 \mathrm{~h}\right)$ after filtering water samples, and particulate $\mathrm{N}$ was analysed in a Fisons NA $1500 \mathrm{CN}$ analyzer. The HS flocculated to some extent in the experimental bottles. To avoid getting this flocculated material on the filters when filtering for analysis of particulate $N$, the water samples were first sonicated using a Heat Systems Ultrasonic processor XL with a microtip ( $3 \mathrm{~min}, 50 \%$ effect) in order to disrupt the flocs. This treatment disrupted the flocs while the P. minimum cells were still in good shape and did not decrease in number. To further ensure that no humic material should end up on the filters, the samples were filtered through a $10 \mu \mathrm{m}$ mesh size nylon net which let remaining smaller particles or cells pass, but 
retained the $P$. miniumum cells. The $P$. minimum cells were then back-flushed in a smaller volume of GF/F filtered seawater and filtration through the precombusted Whatman GF/F filters was performed. A subsample $(2 \mathrm{ml})$ was taken out, fixed with Lugol's solution and the concentration of $P$. minimum cells was determined by microscopy using a $0.1 \mathrm{ml}$ PalmerMaloney counting chamber. Thus, it was later possible to calculate the number of $P$. minimum cells on the filters. Controls were also analyzed, by processing water from the control bottles with humic addition in the same way as above. The amount of $\mathrm{N}$ obtained on these filters was subtracted from the concentrations calculated based on the results from the filters containing $P$. minimum cells, in proportion to the volume of $P$. minimum concentrate that was filtered (the amount of $\mathrm{N}$ subtracted in this way was always less than $5 \%$ of the $\mathrm{N}$ assumed to be in $P$. minimum cells).

Bacteria nitrogen content was calculated by assuming a bacterial $\mathrm{C}: \mathrm{N}$ ratio of 4.5 and a mean cell $\mathrm{C}$ content of $20 \mathrm{fg} \mathrm{C}$ cell $^{-1}$ (Goldman et al. 1987, Lee \& Fuhrman 1987). Nitrogen content in the Cafeteria roenbergensis cells was calculated by assuming a $\mathrm{C}: \mathrm{N}$

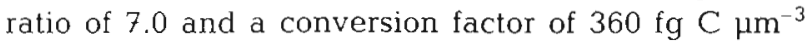
(Verity et al. 1992), and the volume of the C. roenbergensis cells was estimated to be approximately $10 \mathrm{\mu m}^{-3}$ after microscopical measurements of linear dimensions.

\section{RESULTS}

\section{Bacterial growth}

The bacterial biomass increased several-fold in the treatments with only bacteria (BACT and BACT+HS) or bacteria together with Prorocentrum minimum (PMIN and PMIN+HS) (Mann Whitney $U$-test, $\mathrm{p}<0.05$ ) (Fig. 1). Bacterial numbers were significantly higher at the end of the incubation period in the HS treatments with only bacteria (BACT $+\mathrm{HS}$ ) or bacteria and $P$. minimum (PMIN+HS) than in the treatments without HS (Mann Whitney $U$-test, $\mathrm{p}<0.05$ ). Also the bacterial production became significantly higher in the HS treatments than in the treatments without HS during the second half of the experiment (Mann Whitney $U$ test, $p<0.05$, Fig. 2), except in the treatments with both Cafeteria roenbergensis and $P$. minimum (CAF+PMIN and CAF+PMIN+HS). The HS were thus a substrate which the bacteria to some extent utilized after a lag phase of approximately $3 \mathrm{~d}$ (see Fig. 2). In the treatments with $C$. roenbergensis the bacterial numbers were kept low due to the grazing activity of the heterotrophic flagellates.

\section{Growth of Cafeteria roenbergensis}

The abundance of Cafeteria roenbergensis was significantly higher in the CAF+HS treatment $(51000$ cells $\mathrm{ml}^{-1}$ ) than in the CAF treatment ( 38000 cells ml ${ }^{-1}$ ) at the end of the experiment (Mann Whitney $U$-test, 

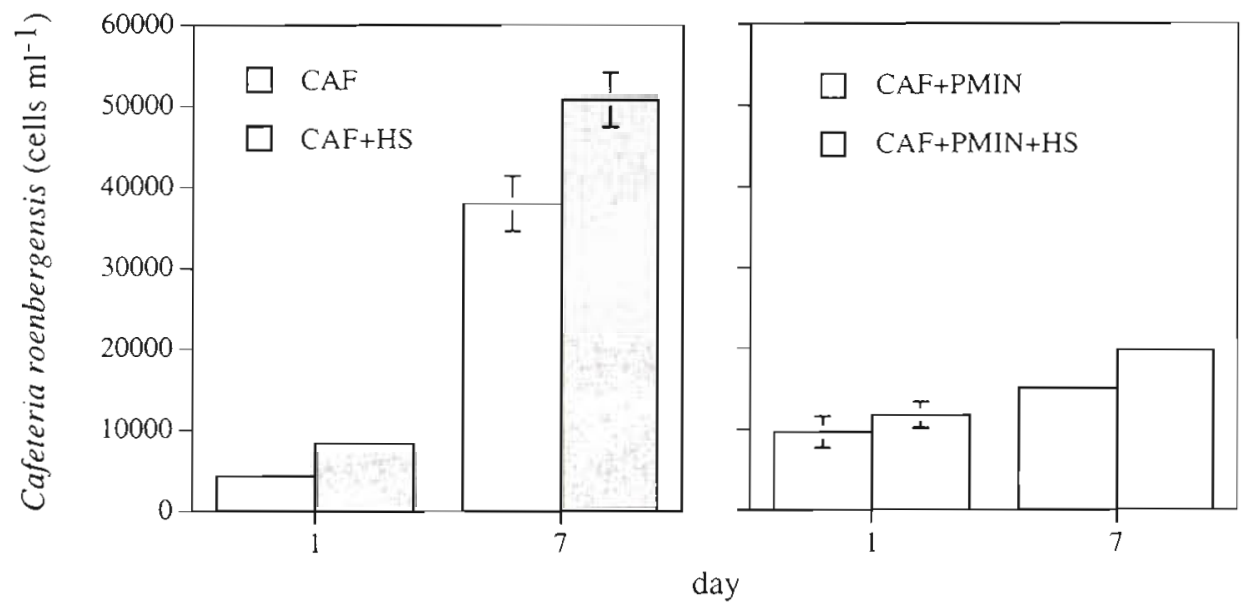

Fig. 3. Cafeteria roenbergensis. Abundance (cells $\mathrm{ml}^{-1}$ ) on Days 1 and 7. Treatments as in Fig. $1(\mathrm{n}=3, \mathrm{mean} \pm \mathrm{SD})$

$\mathrm{p}<0.05$, Fig. 3), showing that the increased bacterial growth in the HS treatments also increased the growth of their grazers. In the CAF+PMIN+HS treatment, the number of $C$. roenbergensis cells was also significantly higher than in the corresponding non-humic treatment (CAF+PMIN) (Mann Whitney $U$-test, $\mathrm{p}<0.05$ ). However, the difference between the humic and non-humic treatment was less marked when Prorocentrum minimum was present. In fact, the abundance of $C$. roenbergensis was lower in both treatments with $P$. minimum cells present than in the treatments without $P$. minimum (Mann Whitney $U$-test, $\mathrm{p}<0.01$ ).

\section{Growth of Prorocentrum minimum}

The cell numbers, chl a concentration and primary production were significantly higher in the PMIN+HS treatment compared to the PMIN treatment when maximum biomass/production was recorded (Days 5 and 7) (Mann Whitney $U$-test, $\mathrm{p}<0.05$, Fig. 4) showing that the HS addition also stimulated the growth of the alga. Prorocentrum minimum in the PMIN+HS treatment also showed a significantly higher chl a concentration, cell number and primary production than in the treatment with Cafeteria roenbergensis (PMIN+ CAF+HS) (Mann Whitney $U$-test, $\mathrm{p}<0.05$ ). Chl a content per cell was significantly higher in the PMIN+HS treatment than in the PMIN treatment $(21.6$ compared to $5.9 \mathrm{pg}$ chl a $\mathrm{cell}^{-1}$ during the exponential growth phase (Day 4) (Mann Whitney $U$-test, p $<0.05$ ). Also the primary production per cell was significantly higher in the PMIN+HS treatment than in the PMIN treatment (maximum difference on Day 5 with 45.9 compared to $9.3 \mathrm{pg} \mathrm{C}$ cell ${ }^{-1} \mathrm{~h}^{-1}$ ) (Mann Whitney $U$-test, $p<0.05)$.

\section{Inorganic nutrients}

The concentrations of inorganic $\mathrm{N}\left(\mathrm{NO}_{3}{ }^{-}+\mathrm{NH}_{4}{ }^{+}\right)$and phosphate in the initial water used in the experiment were about $1.2 \mu \mathrm{M}$ and $0.2 \mu \mathrm{M}$, respectively (Fig. 5). The addition of HS increased the nitrate concentration by 0.1 to $0.2 \mu \mathrm{M}$, but did not change the ammonium and phosphate concentrations significantly. The increase in nitrate concentration when HS was added was low compared to the total $\mathrm{N}$ added to the HS $\left(6.2 \mu \mathrm{M} \mathrm{N}^{-1}\right)$. The initial ratio between inorganic $\mathrm{N}$ and $P$ after the addition of the HS and the addition of Prorocentrum minimum and/or Cafeteria roenbergensis was about $7: 1$, i.e. there was a shortage of $\mathrm{N}$ according to the Redfield ratio (16:1). The HS contained $0.3 \%$ $\mathrm{N}$ and $0.01 \% \mathrm{P}$, suggesting that the HS would cause a $P$ limitation of both bacterial and phytoplankton production if $\mathrm{N}$ and $\mathrm{P}$ were equally available from the HS, and provided that available organic $C$ for the bacteria was in surplus in the HS. No extra $P$ was added to any treatment, but since no detectable activity of alkaline phosphatase developed during the experiment $\left(<0.5 \mathrm{nmol} \mathrm{P} \mathrm{min}^{-1}\right.$ for all measurements, data not shown), sufficient inorganic $P$ was probably present for bacterial and phytoplankton growth. Phosphate concentrations were around or below $0.2 \mu \mathrm{M}$, except in the treatments with $C$. roenbergensis, where the concentrations increased, indicating that regenerated phosphate accumulated by the grazing of $C$. roenbergensis on bacteria

The concentration of nitrate generally decreased in all treatments and was below $0.5 \mu \mathrm{M}$ at the end of the experiment, except in the CAF+PMIN+HS treatment, where there was about $0.9 \mu \mathrm{M}$ of nitrate at the end. The concentration of ammonium was relatively constant around or below $0.2 \mu \mathrm{M}$ in all treatments during 

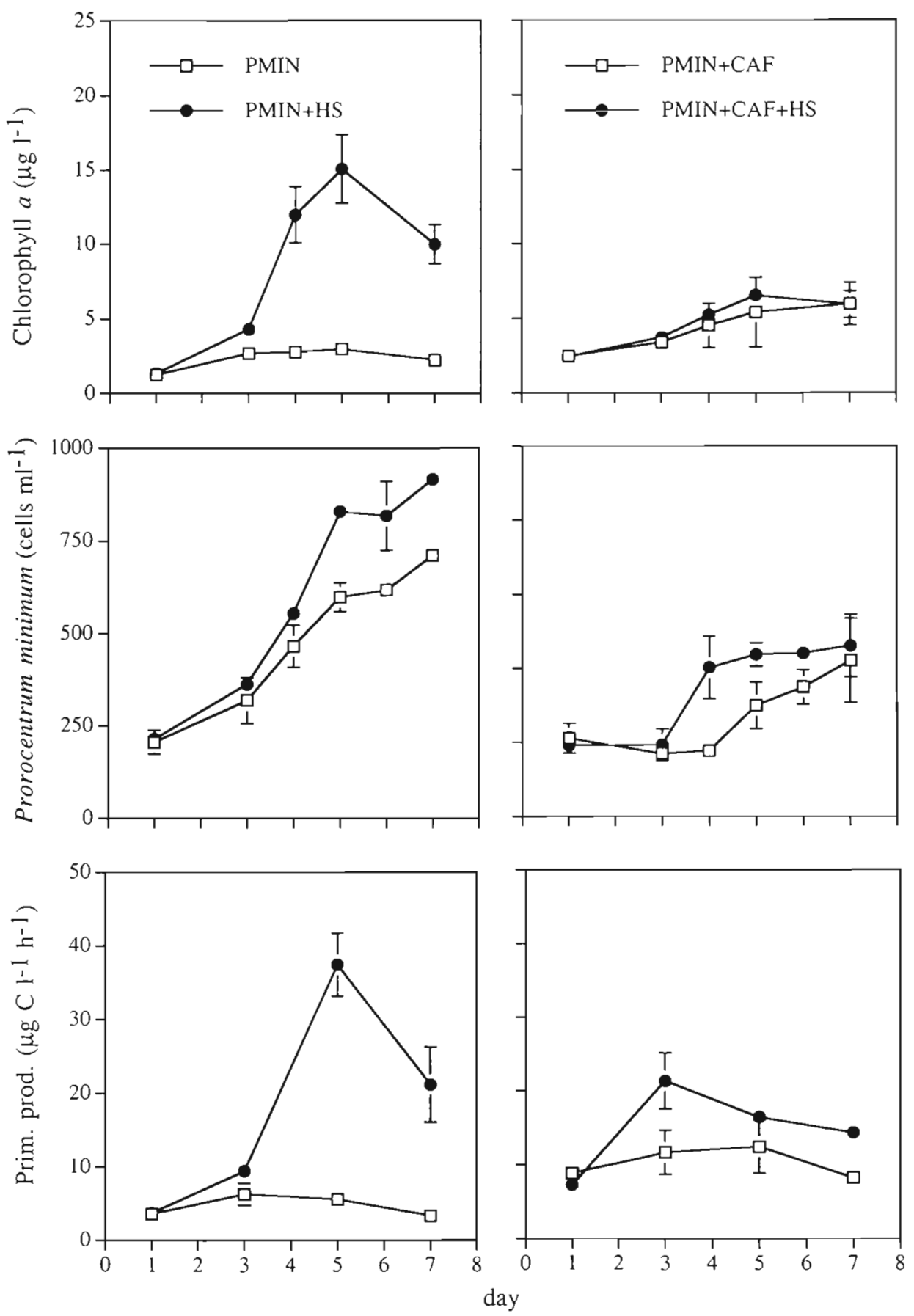

Fig. 4. Chlorophyll a concentration ( $\mu \mathrm{g} \mathrm{I}^{-1}$ ), cell numbers of Prorocentrum minimum (PMIN) (cells ml ${ }^{-1}$ ) and primary production $\left(\mu \mathrm{g} \mathrm{C} \mathrm{l}^{-1} \mathrm{~h}^{-1}\right)$ in the humic (HS) and non-humic treatments, with or without additions of Cafeteria roenbergensis $(\mathrm{CAF})(\mathrm{n}=3$, mean $\pm \mathrm{SD}$ )

the experimental period and no accumulation of ammonium could be seen in the treatments with bacteria only or bacteria and Cafeteria roenbergensis, indicating that there was no net release of ammonium due to bacterial mineralization or any net increase of ammonium released by grazing activity.

\section{Particulate nitrogen in bacteria, Cafeteria roenbergensis and Prorocentrum minimum}

The amount of $\mathrm{N}$ per cell in Prorocentrum minimum in the PMIN+HS treatment increased from $25 \mathrm{pg} \mathrm{N}$ cell $^{-1}$ to $35 \mathrm{pg} \mathrm{N}$ cell ${ }^{-1}$, which made the intracellular $\mathrm{N}$ 

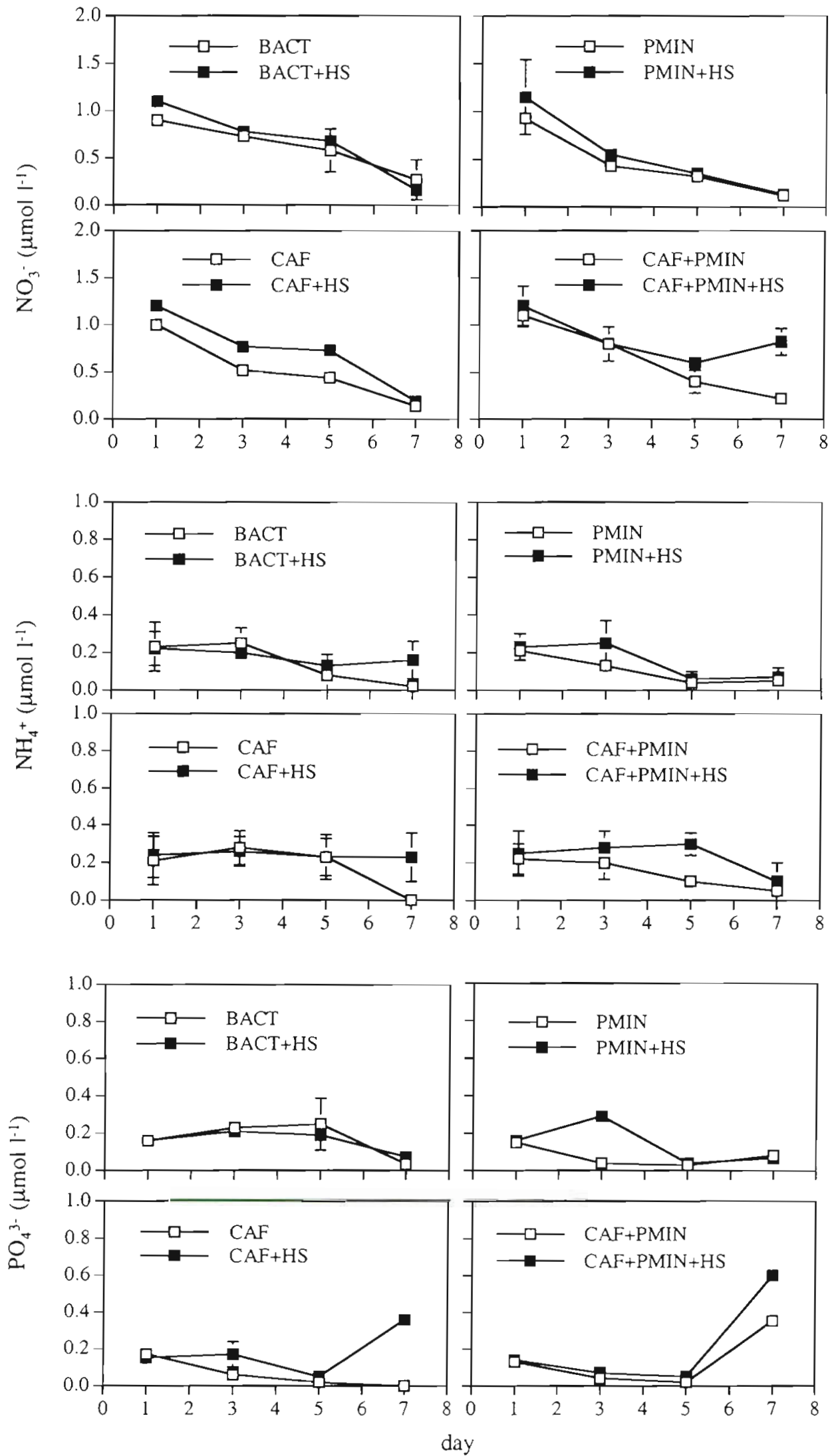

Fig. 5. Concentrations of inorganic nutrients (nitrate, ammonium and phosphate) $(\mu \mathrm{M})$. Treatments as in Fig. $1(\mathrm{n}=3$, mean $\pm \mathrm{SD}$ ) 

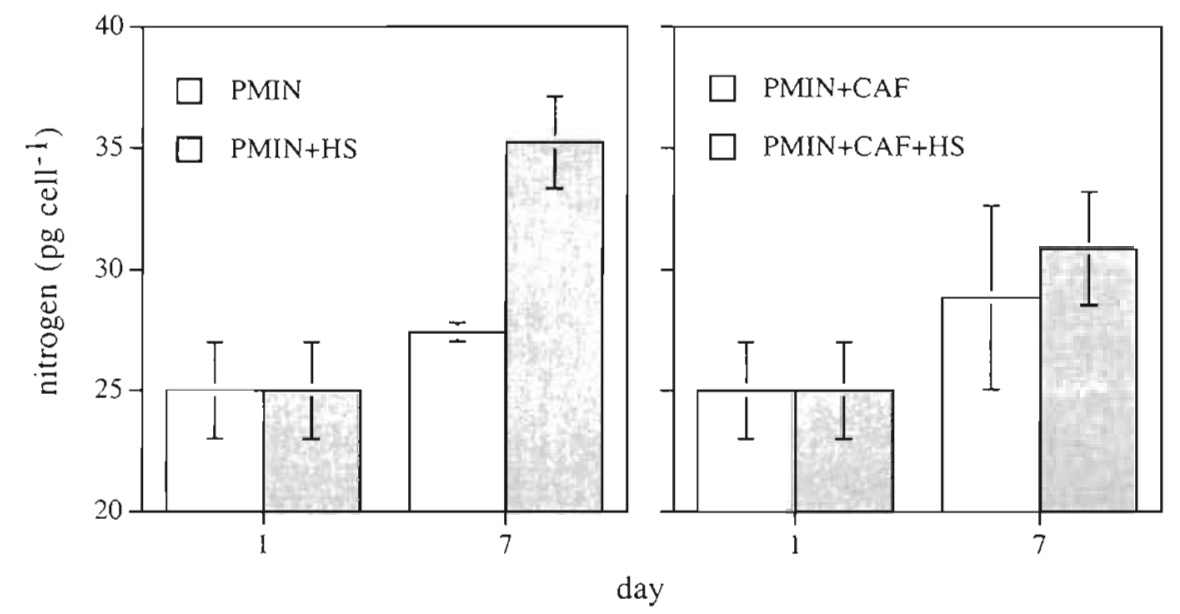

Fig. 6. Nitrogen content (pg cell ${ }^{-1}$ ) in Prorocentrum minimum (PMIN) cells in the treatments with or without additions of humic substances (HS) and Cafeteria roenbergensis (CAF), on Days 1 and 7 ( $n=3$, mean $\pm \mathrm{SD}$ )

content in $P$. minimum significantly higher in the PMIN+HS treatment compared to the PMIN treatment at the end of the experiment (Mann Whitney $U$-test, $\mathrm{p}<0.05$, Fig. 6). In the treatment with addition of Cafeteria roenbergensis, however, there was no significant difference in the $\mathrm{N}$ content per cell of $P$. minimum in the HS treatments compared to the non-humic treatments, although a significant increase in intracellular $\mathrm{N}$ content in the PMIN+CAF+HS treatment could be observed compared to initial $N$ content (Mann Whitney $U$-test, $\mathrm{p}<0.05$ ).

Table 1. Particulate nitrogen concentration $(\mu \mathrm{M})$ in bacteria, phytoplankton and heterotrophic flagellates. For bacteria a mean cell carbon content of $20 \mathrm{fg} \mathrm{cell}^{-1}$ and a C: $\mathrm{N}$ ratio of 4.5 was assumed. For Prorocentrum minimum, the $\mathrm{N}$ content per cell determined with the $\mathrm{CN}$ analyzer was used. For Cafeteria roenbergen-

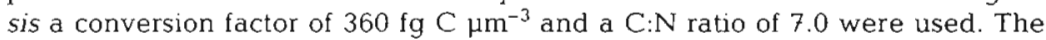
mean volume of $C$. roenbergensis was determined by microscopical measurements to be approximately $10 \mathrm{\mu m}^{3}$. The calculated $\mathrm{N}$ content was $0.51 \mathrm{pg} \mathrm{N}$ cell $^{-1}($ mean $\pm S D, n=3)$

\begin{tabular}{|c|c|c|c|c|}
\hline & Bacteria & P. minimum & C. roenbergensis & Sum \\
\hline Initial: & $\begin{array}{l}0.13 \pm 0.06 \\
0.29 \pm 0.15^{a}\end{array}$ & $0.38 \pm 0.04$ & $0.43 \pm 0.06$ & $\begin{array}{l}0.94 \pm 0.07 \\
1.10 \pm 0.01\end{array}$ \\
\hline \multicolumn{5}{|l|}{ Day 7} \\
\hline $\mathrm{BACT}$ & $1.31 \pm 0.08$ & - & - & $1.31 \pm 0.08$ \\
\hline $\mathrm{BACT}+\mathrm{HS}$ & $1.67 \pm 0.12$ & - & - & $1.67 \pm 0.12$ \\
\hline PMIN & $1.63 \pm 0.09$ & $1.36 \pm 0.02$ & - & $2.99 \pm 0.11$ \\
\hline PMIN+HS & $2.04 \pm 0.18$ & $2.31 \pm 0.05$ & - & $4.35 \pm 0.17$ \\
\hline CAF & $0.29 \pm 0.02$ & - & $1.38 \pm 0.12$ & $1.67 \pm 0.15$ \\
\hline $\mathrm{CAF}+\mathrm{HS}$ & $0.24 \pm 0.05$ & - & $1.85 \pm 0.12$ & $2.09 \pm 0.17$ \\
\hline CAF+PMIN & $0.31 \pm 0.06$ & $0.87 \pm 0.20$ & $0.54 \pm 0.01$ & $1.72 \pm 0.16$ \\
\hline $\mathrm{CAF}+\mathrm{PMIN}+\mathrm{HS}$ & $0.26 \pm 0.10$ & $1.02 \pm 0.15$ & $0.72 \pm 0.03$ & $2.00 \pm 0.19$ \\
\hline
\end{tabular}

The measured/estimated particulate $\mathrm{N}$ concentration in bacteria, Prorocentrum minimum and Cafeteria roenbergensis was higher in the humic treatments than in the non-humic treatments at the end of the experiment, except for bacteria in the treatments with C. roenbergensis (Table 1). The highest particulate $\mathrm{N}$ concentration in organisms was obtained in the PMIN+HS treatment $(4.35 \pm 0.17 \mu \mathrm{M})$. The calculated concentration of particulate $\mathrm{N}$ in bacterial cells at the end of the experiment was also significantly higher in the BACT+HS treatment compared to the BACT treatment and in the bacterial cells in the treatments with $P$. minimum present (PMIN compared with BACT and PMIN+HS compared with BACT+HS) (Mann Whitney $U$-test, $\mathrm{p}<0.05$ ).

\section{DISCUSSION}

The addition of riverine HS stimulated growth of marine bacteria, the heterotrophic nanoflagellate Cafeteria roenbergensis, and the photosynthetic dinoflagellate Prorocentrum minimum. The experiment points out the complexity of all interactions that arise in a 3-member artificial microbial system regarding bacterial substrate quality, bacterial abundance/ growth, grazing activity of heterotrophic flagellates and growth of autotrophs. However, the experiment gives information about what potentially can happen when freshwater HS is processed by a planktonic 
microbial food web in a coastal marine system. The most important results were: (1) a significant amount of the humic $N$ was utilized by the organisms, (2) bacteria acted as a sink for $\mathrm{N}$ when utilizing the HS as substrate, since no increase of inorganic $N$ concentrations could be observed in the treatments with only bacteria, and (3) grazer-mediated remineralization was of little or no importance for the growth of $P$. minimum, since no increase of inorganic $N$ concentrations could be observed in the treatments with bacteria and C. roenbergensis. However, some inorganic N, regenerated by $C$. roenbergensis grazing on bacteria, may have been available for both $P$. minimum and bacteria, but so rapidly utilized that no concentration increase could be detected.

\section{Bacterial utilization of HS}

HS are to some extent available to bacterial degradation, as shown in this experiment and elsewhere (e.g. De Haan 1974, Tranvik 1988, Moran \& Hodson 1990). The concentration of DOC in the original coastal seawater used in the experiment was $10 \mathrm{mg} \mathrm{Cl}^{-1}$, and the addition of HS increased the DOC concentration by $3.5 \mathrm{mg} \mathrm{Cl}^{-1}$. The addition of HS can be considered as a natural increase in HS concentration in coastal waters close to river mouths, since open waters in the Kattegat/Skagerrak area have concentrations of HS up to $2 \mathrm{mg} \mathrm{l}^{-1}$ and DOC concentrations of up to $4 \mathrm{mg} \mathrm{l}^{-1}$ (Wedborg et al. 1994).

The bacterial production increased in the HS treatments after a lag phase of 3 to $4 \mathrm{~d}$. It is possible that the original bacterial community in the $0.2 \mu \mathrm{m}$ filtrate could not directly use the HS as a substrate. Instead a succession in the bacterial community in the direction towards species more adapted to utilize the HS could have taken place. The high bacterial production in the HS treatments did not increase bacterial biomass to any large extent (although significant) compared to the non-humic treatments. This was probably due to a low growth efficiency of the bacteria. Amon \& Benner (1996) showed that bacterial growth efficiency was lower ( 8 to $39 \%$ ) when bacteria were using HMW DOM compared to LMW DOM (16 to 66\%). However, the total bacterial utilization of DOC was higher for HMW DOM than for LMW DOM (Amon \& Benner 1996). HS isolated by using a XAD-8 resin do not separate the DOM into HMW and LMW compounds, but the river water from which we isolated the HS had a high content of colored substances indicating a high concentration of HMW compounds, and it is therefore reasonable to assume that the HS isolated for this experiment consisted mainly of HMW compounds (Aho 1986, Tranvik 1990).
The $\mathrm{C}: \mathrm{N}$ ratio of isolated riverine $\mathrm{HS}$ is normally around 50 (by weight) (Malcolm 1985). The HS used in this experiment had a $\mathrm{C}: \mathrm{N}$ ratio of 40 . The $\mathrm{C}: \mathrm{N}$ ratio of the bacterial substrate is an important factor to consider when determining whether bacteria will be a source or a sink for $N$ (e.g. Fenchel \& Blackburn 1979). If $N$ in the organic substrate is insufficient for growth, the bacteria will assimilate additional $\mathrm{N}$ from the pool of inorganic $N$ (such as ammonium) (Wheeler \& Kirchman 1986, Zweifel et al. 1993). Net mineralization of $N$ would occur only when the bacterial substrate has a $\mathrm{C}: \mathrm{N}$ ratio less than 10 (Goldman et al. 1987. Tezuka 1990), assuming that the relative availability for bacteria of the $\mathrm{C}$ and $\mathrm{N}$ is the same. If not the $\mathrm{C}$ in the HS is much more refractory than the $\mathrm{N}$, and it can therefore be assumed that the bacteria would be a sink for the $\mathrm{N}$ and not remineralize $\mathrm{N}$ in the treatments with HS. Since the ammonium concentration in the treatment with only bacteria and HS was constantly low throughout the experiment, the high $\mathrm{C}: \mathrm{N}$ ratio of the HS accurately predicted that bacteria were a sink for $\mathrm{N}$.

\section{Interactions between bacteria, Cafeteria roenbergensis and Prorocentrum minimum}

Previously it was generally assumed that bacteria were the main remineralizers of organic matter in the sea and made inorganic nutrients available for phytoplankton uptake. This view has changed, since $\mathrm{N}$ demand of bacterial growth cannot be met by the utilizable DON pool in seawater (Wheeler \& Kirchmann 1986, Goldman et al. 1987). Grazing by bacterivorous protozoa is in these instances considered to be the primary mechanism for the remineralization of $\mathrm{N}$ contained in the bacterial biomass (Johannes 1965, Azam et al. 1983, Caron \& Goldman 1990). Protozoans are thus the most important organisms for the regeneration of both inorganic P and N (e.g. Azam et al. 1983, Caron \& Goldman 1990) and the bacterial contribution to net regeneration is quite small, since bacteria are also actively assimilating inorganic $N$ and $\mathrm{P}$ (e.g. Pomeroy 1970, Wheeler \& Kirchman 1986, Kirchman 1994). It can therefore be expected that a growth stimulation of phytoplankton in an experiment with addition of HS would arise from inorganic nutrients regenerated via protozoan grazing on bacteria that assimilated some of the humic-bound nutrients. Such a response was reported by Carlsson et al. (1993) in a mesocosm experiment with a natural coastal plankton community, where humic substances increased bacterial, protozoan, and phytoplankton growth. In this experiment we expected a similar outcome. In contrast, however, there was no growth stimulation of the 
phytoplankton when Cafeteria roenbergensis was added. Instead, Prorocentrum minimum grew better in the treatments without $C$. roenbergensis, suggesting that grazer-mediated remineralization of inorganic $N$ was of little importance. It is surprising, however, that no increase in the ammonium concentrations was detected in the treatments with $C$. roenbergensis and bacteria (without $P$. minimum). This was probably caused by a direct utilization of the regenerated ammonium by the bacteria.

Cafeteria roenbergensis fed on bacteria and reached higher numbers in the HS treatments. Growth of $C$. roenbergensis probably lagged some days behind the growth of bacteria, as observed elsewhere in natural communities (Azam et al. 1983, Andersen \& Sørensen 1986) and in laboratory studies (Fenchel 1982, Tranvik \& Sieburth 1989). Thus, $C$. roenbergensis had probably not reached their maximum cell density when the experiment ended on Day 7 , especially since bacterial production was still increasing in the treatments with $C$. roenbergensis. Therefore it is possible that additional inorganic $\mathrm{N}$ would have become available for Prorocentrum minimum in the treatments with $C$. roenbergensis after Day 7. However, chl a concentrations and primary production rates were stable or decreasing on Day 7 in all treatments with $C$. roenbergensis, indicating that the growth of $P$. minimum had ceased due to $\mathrm{N}$ limitation in these treatments.

\section{Growth of Prorocentrum minimum}

Phytoplankton growth has been shown to be stimulated by HS (e.g. Prakash \& Rashid 1968, Granéli et al. 1985. Carlsson et al. 1993). The stimulation of phytoplankton growth by HS has sometimes been attributed to chelation of trace metals by the HS, either by 'detoxifying' the water (e.g. Toledo et al. 1982) or by making necessary trace metals more available for phytoplankton (Prakash \& Rashid 1968, Anderson \& Morel 1982). Also the $\mathrm{N}$ present in organic form in soil humic extracts used in culture media has been suggested to be beneficial for phytoplankton. Morril \& Loeblich (1979) found that N-limited axenic cultures of Kryptoperidinium foliaceum increased in growth rate and biomass yield when supplied with sterile soil extract, probably because of the organic $\mathrm{N}$ content, and Ogata et al. (1996) observed high growth of Alexandrium tamarense when $\mathrm{N}$-limited semi-continuous cultures were supplied with yeast extract and suggested that $A$. tamarense was able to utilize organic $N$ substances for growth and toxin production. Granéli et al. (1985) suggested that Prorocentrum minimum was able to use $\mathrm{N}$ in HS, either directly or after bacterial mineraliztion, since the biomass yield increased when HS and phosphate were added. The cellular $N$ content of $P$. minimum grown with addition of HS in the experiment by Granéli et al. (1985) was also comparable to cells grown with inorganic N. In our experiment, we added trace metals according to $1 / 10$ of the $\mathrm{f} / 2$ medium (Guillard \& Ryther 1962) to all treatments. Thus, it seems unlikely that the lower growth of $P$. minimum in the non-humic treatments was caused by trace metal limitation. Instead, phytoplankton growth was probably limited by the available $\mathrm{N}$ in all treatments, and the extra utilizable $\mathrm{N}$ that was present in the HS treatments made a larger biomass increase possible. The low concentrations of inorganic $\mathrm{N}$ in all treatments and the absence of alkaline phosphatase activity also suggest that $\mathrm{N}$ limited the growth of $P$. minimum at the end of the experiment.

The high growth observed for Prorocentrum minimum in the treatment with HS added (without Cafeteria roenbergensis) cannot be explained by the inorganic $N$ concentrations present initially. Moreover, since there was no detectable net accumulation of ammonium in the treatment with bacteria and HS, it is possible that $P$. minimum utilized DON. $P$. minimum might have used e.g. amino acids that were associated with the HS. Amino acids can be utilized by phytoplankton at environmentally relevant concentrations (e.g. Flynn \& Butler 1986, Antia et al. 1991) and a significant amount of amino acids can be bound to dissolved HMW compounds (Carlson et al. 1985). The extraction procedure we used to concentrate HS would also have caused a precipitation of the polypeptides in the river water due to the acidification of the sample before eluting it through the XAD column (Thurman 1985), and Lytle \& Perdue (1981) found that $97 \%$ of the amino acids present in river water would be extracted using the XAD extraction procedure. Amino acids can also be released from river-isolated HS: when riverine $\mathrm{HS}$ is added to sterile seawater such that the DOC concentration increases by $10 \mathrm{mg}$ $\mathrm{l}^{-1}$, the concentrations of dissolved free amino acids and dissolved combined amino acids can increase by 6 to $7 \mathrm{\mu mol} \mathrm{l}^{-1}$ (Carlsson et al. 1998).

\section{Particulate nitrogen in bacteria, Cafeteria roenbergensis and Prorocentrum minimum}

Particulate $\mathrm{N}$ increase in bacteria and Prorocentrum minimum in the HS treatment when these organisms were grown together, compared to the BACT+HS treatment, indicates that the uptake of $N$ from the medium (inorganic $\mathrm{N}$ and $\mathrm{N}$ associated with the $\mathrm{HS}$ ) doubled when $P$. minimum was present. The highest biomass of $P$. minimum and Cafeteria roenbergensis 
was produced in the treatments where these organisms were grown separately with HS, but when they were grown together, both had a lower biomass at the end of the experiment. It is interesting to note that the sum of the particulate $N$ in the $C$. roenbergensis and $P$. minimum cells when grown together $(1.41 \mu \mathrm{M} N$ without HS and 1.74 $\mu \mathrm{MN}$ with HS) is similar to the particulate $\mathrm{N}$ in these organisms when grown alone $(C$. roenbergensis without or with HS: 1.38 and $1.85 \mu \mathrm{MN}$ respectively; $P$. minimum: 1.36 and $2.31 \mu \mathrm{MN}$, respectively). Thus, the available $\mathrm{N}$ was partitioned between the 2 organisms when they were grown together.

By using (1) the concentration of known dissolved $\mathrm{N}$ when the experiment started (in total $7.70 \mu \mathrm{M}$, of which $1.50 \mu \mathrm{M}$ was inorganic and $6.20 \mu \mathrm{M}$ associated with the HS), (2) the increase in particulate $N$ (from $0.67 \mu \mathrm{M}$ to $4.35 \mu \mathrm{M}$ ) in bacteria and Prorocentrum minimum in the PMIN+HS treatment and (3) the remaining inorganic $N$ concentration at the end of the experiment $(0.15 \mu \mathrm{M})$, the amount of humic-associated $N$ taken up by the organisms can be roughly estimated, assuming no net change in the unknown part of the DON pool. The humic-associated $\mathrm{N}$ left in the medium after uptake by bacteria and $P$. minimum would be: $(1.50+6.20+0.67-0.15-4.35) \mu \mathrm{M}=3.87 \mu \mathrm{M}$, i.e. 6.02 $-3.87=2.33 \mu \mathrm{M}$ of the humic-associated $\mathrm{N}$ was perhaps taken up by the bacteria and $P$. minimum, which is $37 \%$ of the initial humic-associated $N[(2.33 / 6.2) \times$ $100]$. In treatments with Cafeteria roenbergensis, the percentage of initially humic-associated $\mathrm{N}$ present in the organisms on Day 7 was less ( 8 to $20 \%$ ).

\section{Competition between bacteria and Prorocentrum minimum}

It has been shown in experiments (Currie \& Kalff 1984, Pengerud et al. 1987) and modelled mathematically (Bratbak \& Thingstad 1985) that bacteria can compete effectively with phytoplankton for inorganic nutrients under certain conditions. Because of the bacterial superiority when competing for inorganic nutrients, a significantly reduced growth of Prorocentrum minimum would be expected in the treatments with bacteria at low inorganic $\mathrm{N}$ concentrations. This has been shown experimentally for both P- (Currie \& Kalff 1984) and N-limited (Caron et al. 1988) phytoplankton cultures which were negatively affected by bacterial competition for inorganic $\mathrm{P}$ or $\mathrm{N}$ after addition of glucose as a $C$ source. In our experiment, however, there was an apparent absence of competition between bacteria and $P$. minimum for $N$. Perhaps the time span of this experiment was too short for any significant competition for $\mathrm{N}$ between bacteria and $P$. minimum to develop, compared to the amount of available $N$.

\section{CONCLUSIONS}

About $35 \%$ of the organic $N$ supplied with the HS ended up in bacteria and Prorocentrum minimum cells after $1 \mathrm{wk}$ of incubation. Bacteria acted as a sink for the humic-bound $\mathrm{N}$ they utilized, and grazing activity by the heterotrophic flagellate Cafeteria roenbergensis did not increase the growth of the dinoflagellate $P$. minimum by remineralizing inorganic $N$. Thus, riverine $\mathrm{HS}$ are to some extent utilized by coastal bacteria after a lag phase of a few days and some of the $\mathrm{N}$ supplied with the HS ends up in bacterial biomass and biomass of bacterial grazers. The amount of $\mathrm{N}$ that becomes available as inorganic $\mathrm{N}$ for phytoplankton growth can be relatively small. The increased growth of $P$. minimum with HS present was thus probably not caused by bacterial or grazer mineralization of inorganic nitrogen, but might have been due to $P$. minimum utilization of DON compounds.

Acknowledgements. This study was supported by funds from the Swedish Environmental Protection Agency (SNV) (contract holder P.C.) and the Swedish Board for Agricultural and Forestry Research (contract holder E.G.). We thank Simonetta della Libera and Sandra Lange for helping us with phytoplankton and bacteria counting and the measurements of alkaline phosphatase activity. We also thank David A. Caron and 2 anonymous reviewers for valuable comments on the manuscript

\section{LITERATURE CITED}

Ertebjerg-Nielsen G, Bresta AM (1984) Guidelines for the measurement of phytoplankton primary production, 2nd edn. The Baltic Marine Biologists (BMB) Publ no. 2, Charlottenlund

Aho J (1986) Size exclusion chromatograms of dissolved humic material in oligo-, meso-, and polyhumic lakes and in ground water. Arch Hydrobiol 107:301-314

Albright LJ (1983) Influence of river-ocean plumes upon bacterioplankton production in the Strait of Georgia, British Columbia. Mar Ecol Prog Ser 12:107-113

Amon R, Benner R (1996) Bacterial utilization of different size classes of dissolved organic matter. Limnol Oceanogr 41 : 41-51

Andersen P, Sorensen HM (1986) Population dynamics and trophic coupling in pelagic microorganisms in eutrophic coastal waters. Mar Ecol Prog Ser 33:99-109

Anderson MA, Morel FMM (1982) The influence of aqueous iron chemistry on the uptake of iron by the coastal diatom Thalassiosira weissflogii. Limnol Oceanogr 27:789-813

Andersson T, Nilsson $\AA$, Jansson M (1991) Coloured substances in Swedish lakes and rivers - temporal variation. and regulating factors. In: Allard B, Borén H, Grimvall A (eds) Humic substances in the aquatic and terrestrial environment. Lecture notes in earth sciences, Vol 33. SpringerVerlag, Berin, p 243-253

Antia NJ, Harrison PJ, Oliviera L (1991) The role of dissolved organic nitrogen in phytoplankton nutrition, cell biology and ecology. Phycol 30:1-89

Azam F, Fenchel T, Field JG, Gray JS, Thingstad F (1983) The 
ecological role of water-column microbes in the sea. Mar Ecol Prog Ser 19:257-263

Bratbak G, Thingstad TF (1985) Phytoplankton-bacteria interactions: an apparent paradox? Analysis of a model system with both competition and commensalism. Mar Ecol Prog Ser 25:23-30

Bushaw KL, Zepp RG, Tarr MA, Schulz-Janders D, Bourbonniere RA, Hodson RE, Miller WL, Bronk DA, Moran MA (1996) Photochemical release of biologically available nitrogen from aquatic dissolved organic matter. Nature 381:404-407

Carlson DJ, Mayer LM, Brann ML, Mague TH (1985) Binding of monomeric organic compounds to macromolecular dissolved organic matter in seawater. Mar Chem 16:141-153

Carlsson P, Granéli E (1993) Availability of humic bound nitrogen for coastal phytoplankton. Estuar Coast Shelf Sci $36: 433-447$

Carlsson P, Segatto AZ, Granéli E (1993) Nitrogen bound to humic matter of terrestrial origin - a nitrogen pool for coastal phytoplankton? Mar Ecol Prog Ser 97:105-116

Carlsson P, Granéli E, Tester P, Boni L (1995) Influences of riverine humic substances on bacteria, protozoa, phytoplankton, and copepods in a coastal plankton community. Mar Ecol Prog Ser 127:213-221

Carlsson P, Edling H, Bechemin C (1998) Interactions between a marine dinoflagellate (Alexandrium catenella) and a bacterial community utilizing riverine humic substances. Aquat Microb Ecol 16:65-80

Caron DA, Goldman JC (1990) Protozoan nutrient regeneration. In: Capriulo GM (ed) Ecology of marine protozoa. Oxford University Press, New York, p 283-306

Caron DA, Goldman JC, Dennet MR (1988) Experimental demonstration of the roles of bacteria and bacterivorous protozoa in plankton nutrient cycles. Hydrobiol 159:27-40

Chin-Leo G, Benner R (1992) Enhanced bacterial production and respiration at intermediate salinities in the Mississippi River plume. Mar Ecol Prog Ser 87:87-103

Cotner JB Jr, Gardner WS (1993) Heterotrophic bacterial mediation of ammonium and dissolved free amino acid fluxes in the Mississippi River plume. Mar Ecol Prog Ser 93:75-87

Currie D, Kalff J (1984) Can bacteria outcompete phytoplankton for phosphorus? Microb Ecol 10:205-216

De Haan H (1974) Effect of a fulvid acid fraction on the growth of a Pseudomonas from Tjeukemeer (The Netherlands). Freshw Biol 4:301-310

Fenchel T (1982) Ecology of heterotropic microflagellates. IV. Quantitative occurrence and importance as bacterial consumers. Mar Ecol Prog Ser 9:35-42

Fenchel T, Blackburn TH (1979) Bacteria and mineral cycling. Academic Press, London

Flynn KJ, Butler I (1986) Nitrogen sources for the growth of marine microalgae: role of dissolved amino acids. Mar Ecol Prog Ser 34:281-304

Gardner WS, Benner R, Chin-Leo G, Cotner JB Jr, Eadie B, Cavaletto JF, Lansing MB (1994) Mineralization of organic material and bacterial dynamics in Mississippi River plume water. Estuaries 17:816-828

Geller A (1983) Degradability of dissolved organic lake water compounds in cultures of natural bacterial communities. Arch Hydrobiol 99:60-79

Goldman JC, Caron DA, Dennet MR (1987) Regulation of gross growth efficiency and ammonium regeneration in bacteria by substrate $\mathrm{C}: \mathrm{N}$ ratio. Limnol Oceanogr 32 : $1239-1252$

Granéli E, Moreira MO (1990) Effects of river water of different origin on the growth of marine dinoflagellates and diatoms in laboratory cultures. J Exp Mar Biol Ecol 136: 89-106

Granéli E، Edler L, Gedziorowska D, Nyman U (1985) Influence of humic and fulvic acids on Prorocentrum minimum (Pav.) J. Schiller. In: Anderson DM, White AW, Baden DG (eds) Toxic dinoflagellates. Elsevier Science Publishing Co Inc, New York, p 201-206

Granéli E, Wallström $\mathrm{K}$, Larsson U, Granéli W, Elmgren R (1990) Nutrient limitation of primary production in the Baltic Sea area. Ambio 19:142-151

Guillard RLL, Ryther JH (1962) Studies of marine planktonic diatoms I. Cyclotella nana Hustedt, and Detonula confervacea (Cleve) Gran. Can J Microbiol 8:229-239

Hedges JI (1987) Organic matter in sea water. Nature 330: 205-206

Howarth RW (1988) Nutrient limitation of net primary production in marine ecosystems. Annu Rev Ecol 19:89-110

Jespersen AM, Christoffersen K (1987) Measurements of chlorophyll-a from phytoplankton using ethanol as extraction solvent. Arch Hydrobiol 109:445-454

Johannes RE (1965) Influence of marine protozoa on nutrient regeneration. Limnol Oceanogr 10:434-442

Kirchman D (1994) The uptake of inorganic nutrients by heterotrophic bacteria. Microb Ecol 28:255-271

Kirchman D, Soto Y, Wambeck FV, Bianchi M (1989) Bacterial production in the Rhône River plume: effect of mixing on relationships among microbial assemblages. Mar Ecol Prog Ser 53:267-275

Klut ME, Bisalputra T, Antia NJ (1987) Some observations on the structure and function of the dinoflagellate pusule. Can J Bot 65:736-744

Kullberg A, Petersen RC Jr (1987) Dissolved organic carbon, seston and macroinvertebrate drift in an acidified and limed humic stream. Freshw Biol 17:553-564

Lee S, Fuhrman J (1987) Relationships between biovolume and biomass of naturally derived marine bacterioplankton. Appl Environ Microbiol 53:1298-1303

Legrand C, Carlsson P (1998) Uptake of high molecular weight dextran by the dinoflagellate Alexandrium catenella. Aquat Microb Ecol 16:81-86

Lytle CR, Perdue EM (1981) Free, proteinaceous, and humic bound amino acids in river water containing high concentrations of aquatic humus. Environ Sci Technol 15:224-228

Malcolm RL (1985) Geochemistry of stream fulvic and humic substances. In: Aiken GR, McKnight DM, Wershaw RL (eds) Humic substances in soil, sediment, and water. John Wiley \& Sons, New York, p 181-210

Moran MA, Hodson RE (1990) Bacterial production on humic and nonhumic components of dissolved organic carbon. Limnol Oceanogr 35:1744-1756

Morril LC, Loeblich AR (1979) An investigation of heterotrophic and photoheterotrophic capabilities in marine Pyrrhophyta. Phycol 18:394-404

Ogata T, Koike K, Nomura S, Kodama M (1996) Utilization of organic substances for growth and toxin production by Alexandrium tamarense. In: Yasumoto $T$, Oshima $Y$, Fukuyo Y (eds) Harmful and toxic algal blooms. UNESCO, Sendai, p 343-346

Paerl HW (1993) Emerging role of atmospheric nitrogen deposition in coastal eutrophication: biogeochemical and trophic perspectives. Can J Fish Aquat Sci 50:2254-2269

Palenik B, Morel MM (1990) Comparison of cell-surface Lamino acid oxidases from several marine phytoplankton. Mar Ecol Prog Ser 59:195-201

Payne JW (1980) Microorganisms and nitrogen sources. John Wiley \& Sons, New York

Pengerud B, Skjoldal EF, Thingstad TF (1987) The reciprocal 
interaction between degradation of glucose and ecosystem structure. Studies in mixed chemostat cultures of marine bacteria, algae, and bacterivorous nanoflagellates. Mar Ecol Prog Ser 35:111-117

Petersen RC Jr, Hargeby A, Kullberg A (1987) The biological importance of humic material in acidified waters. Report 3388, Swedish Environmental Protection Agency, Stockholm

Petterson K, Jansson M (1978) Determination of phosphatase activity in lake water - study of methods. Verh Int Verein Theor Angew Limnol 20:1226-1230

Pomeroy LR (1970) The strategy of mineral cycling. Annu Rev Ecol Syst 1:171-190

Porter KG, Feig YS $(1980)$ The use of DAPI for identifying and counting aquatic microflora. Limnol Oceanogr 25:943-958

Prakash A, Rashid MA (1968) Influence of humic substances on the growth of marine phytoplankton: dinoflagellates. Limnol Oceanogr 13:598-606

Price NM, Cochlan WP, Harrison PJ (1985) Time course of uptake of inorganic and organic nitrogen by phytoplankton in the Strait of Georgia: comparison of frontal and stratified communities. Mar Ecol Prog Ser 27:39-53

Raven JA (1980) Nutrient transport in microalgae. Adv Microb Physiol 21:47-226

Rydberg L, Edler L, Floderus S, Granéli W (1990) Interactions between supply of nutrients, primary production, sedimentation and oxygen consumption in SE Kattegat. Ambio 19:134-141

Ryther JH, Dunstan WM (1971) Nitrogen, phosphorus and eutrophication in the coastal marine environment. Science 171:1008-1013

Simon M, Azam F (1989) Protein content and protein synthesis rates of planktonic marine bacteria. Mar Ecol Prog Ser 51:201-213

Smith DC, Azam F (1992) A simple, economical method for measuring bacterial protein synthesis rates in sea water using ${ }^{3} \mathrm{H}$-leucine. Mar Microb Food Webs 6:107-109

Solórzano L, Sharp JH (1980) Determination of total dissolved phosphorus and particulate phosphorus in natural waters. Limnol Oceanogr 25:754-758

Stockner JG. Klut ME, Cochlan WP (1990) Leaky filters: a warning to aquatic ecologists. Can J Fish Aquat Sci 47 : $16-23$

Editorial responsibility: Faroog Azam,

La Jolla, California, USA
Tezuka Y (1990) Bacterial regeneration of ammonium and phosphate as affected by the carbon:nitrogen:phosphorus ratio of organic substrates. Microb Ecol 19:227-238

Thurman EM (1985) Organic geochemistry of natural waters. Martinus/Nijhoff/Dr W Junk Publishers, Boston

Thurman EM, Malcolm RL (1981) Preparative isolation of aquatic humic substances. Environ Sci Technol 15: $463-466$

Toledo APP, D'Aquino VA, Tundisi JG (1982) Influence of humic acid on growth and tolerance to cupric ions in Melosira italica (subsp. antarctica). Hydrobiol 87:247-254

Tranvik LJ (1988) Availability of dissolved organic carbon for planktonic bacteria in oligotrophic lakes of differing humic content. Microb Ecol 311-322

Tranvik LJ (1990) Bacterioplankton growth on fractions of dissolved organic carbon of different molecular weights from humic and clear waters. Appl Environ Microb 56 $1672-1677$

Tranvik LJ, Sieburth JMcN (1989) Effects of flocculated humic matter on free and attached pelagic microorganisms. Limnol Oceanogr 34:688-699

UtermöhI H (1958) Zur Vervollkommung der quantitativen Phytoplankton Methodik. Mitt Int Ver Limnol 9:1-38

Valderrama JC (1995) Methods of nutrient analysis. In: Hallegraeff GM, Anderson DM, Cembella AD (eds) Manual of harmful marine microalge. IOC Manuals and Guides no. 33, UNESCO, Paris, p 251-268

Verity PG, Robertson CY, Tronzo CR, Andrews MG, Nelson JR, Sieracki ME (1992) Relationships between cell volume and the carbon and nitrogen content of marine photosynthetic nanoplankton. Limnol Oceanogr 37: $1434-1446$

Wedborg M, Skoog A, Fogelkvist E (1994) Organic carbon and humic substances in the Baltic Sea, the Kattegat, and the Skagerrak. In: Sienesi N, Miano TM (eds) Humic substances in the global environment and implications on human health. Elsevier, Amsterdam, p 917-924

Wheeler PA, Kirchman DL (1986) Utilization of inorganic and organic nitrogen by bacteria in marine systems. Limnol Oceanogr 31:998-1009

Zweifel UL, Norrman B, Hagström $\AA$ (1993) Consumption of dissolved organic carbon by marine bacteria and demand for inorganic nutrients. Mar Ecol Prog Ser 101:23-32

Submitted: November 25, 1996; Accepted: December 7, 1998 Proofs received from author(s): July 8, 1999 